\title{
Urban Spaces and Architecturally Defined Identity in Nathanael West's Miss Lonelyhearts
}

Wayne E. Arnold

\section{(2) OpenEdition \\ Journals}

Electronic version

URL: https://journals.openedition.org/ejas/10345

DOI: 10.4000/ejas. 10345

ISSN: 1991-9336

Publisher

European Association for American Studies

\section{Electronic reference}

Wayne E. Arnold, "Urban Spaces and Architecturally Defined Identity in Nathanael West's Miss Lonelyhearts", European journal of American studies [Online], 9-2 I 2014, document 3, Online since 26 September 2014, connection on 08 July 2021. URL: http://journals.openedition.org/ejas/10345; DOI: https://doi.org/10.4000/ejas.10345

This text was automatically generated on 8 July 2021.

Creative Commons License 


\title{
Urban Spaces and Architecturally Defined Identity in Nathanael West's Miss Lonelyhearts
}

\author{
Wayne E. Arnold
}

\section{Introduction}

1 On August 1st, 1933, The Greenwich Villager, a New York neighborhood newspaper, featured a front-page article entitled, "Greenwich Village Bows to Modernity." The author lamented the geographical and architectural developments unfolding throughout the previous decade within the dwindling bohemian environments of Greenwich Village, with outdated structures to be sacrificed on the "Altar of Progress" (Watts 1). Outdoor recreational spaces, such as Washington Square, were becoming walled-in by the newly erected structures; apartment buildings infringed upon existing residential zones-one particularly threatened house boasted possession of the last front yard. Such developments were considered challenges to which the city's residents must adjust. A frequent visitor of Greenwich Village, Nathanael West (1903-1940) witnessed the surfacing architectural transformations causing the subsequent emigration of numerous Village artists. West possessed a literary talent that has been noted for being infused with critical and satirical astuteness concerning the core social issues of his generation. Unsurprisingly, West infused his 1933 novella, Miss Lonelyhearts, with images of urban spaces that ultimately define his lead protagonist through the architectural structures of the city. Throughout the novella's rapid-paced narration various locales become keys for interpreting the structural world defining urban life. Places within West's city-an urban park, an underground speakeasy, an office, or even the apartment of the protagonist, Miss Lonelyhearts-function as mirrors that reflect the physically and psychologically oppressed city dweller. Such locations represent what Henri Lefebvre describes as abstract space, various spaces that are multifaceted in their functions due to their shifting-and abstract-relation with a larger environment. I argue that an examination of the physical setting of the 
narrative will illuminate a new understanding of the repressed, agoraphobic identity of Miss Lonelyhearts, and bring a fresh phenomenological interpretation to the demise of one of West's most complicated characters.

2 I have chosen West's second novella due to its sparse prosaic construction and direct references to the surroundings of New York City. Miss Lonelyhearts is a study of actions and emotional responses to an environment of rigid architectonics, depicting a society collapsing inwards. My main argument evolves from the viewpoint that in Miss Lonelyhearts, the personal tribulations the protagonist undergoes are intimately connected with environment-induced confusion. Through an episodic examination of the novella, I demonstrate how the mental collapse of the protagonist is related directly to his surroundings; the individual, West suggests, becomes intertwined with his environment and may fail to rationally overcome agoraphobic tendencies, thereby becoming an abortive incarnation of Georg Simmel's concept of a new public self surmounting the mentally inundating metropolis (338). The culmination of this analysis, I trust, will bring a fresh interpretation to West's work-including a new perspective on the finale-by examining the spaciality within Miss Lonelyhearts.

\section{Literary Architectonics}

3 Literature has long been a source for the cultural examination of urban environments; indeed, examining the Euro-American modern novel "shows that as a culture, we are coming to represent the unrepresentable complexity of this urban world through a thematics of empty space" (Milun 11). Miss Lonelyhearts, as a work structured around environment, encourages the exploration of the 1920s and 30s megalopolis. West's prose is of particular value for period analysis due to his meticulous attention to detail and to his fine-tuning of every produced sentence that leaves the reader with a sense of receiving "striking pictorial effects" (Zlotnick 177).

4 Often praised for his "idiomatic leanness of prose" (Keyes 79), West is less frequently noted for his inclusion of what might be labeled as descriptive asides, seemingly subtle references to windows, walls, doors, rooms, stairwells and high-rises. ${ }^{i}$ Jay Martin, West's official biographer, has observed that in his final novel, The Day of The Locus (1938), West was "fascinated by the architectural" atmosphere of Hollywood. Indeed, West briefly considered incorporating the following epigraph by Lewis Mumford, author of The Culture of Cities (1938): "'From the form of a city, the style of architecture, and the economic functions and social grouping it shelters and encourages, one can derive most of the essential elements of a civilization"' (qtd. in Martin 309).ii After returning from Paris in 1929, having been introduced to the surrealistic movement-known "to encompass architecture" (Bohn 72) in their methodology-West had become enamored with the work of Max Ernst, often looking through "Ernst's books of scrambled illustrations" (Wilson). In paying attention to both the personal, domestic quarters and outer, public spaces comprising the urban environment, West parallels the reflections of his contemporary, Le Corbusier, who published The Radiant City in 1933; for Le Corbusier, future architectural design must transform "the frightening chaos and the saddening monotony of today's cities" (Radiant 301).

5 Recent decades have seen a rise in scholarly examination of place, space and time. Conceivably, we have been "experiencing a resurgence of a model of European 
intellectual history focused on cities" (Spector 259), exploring the space-theories of European and, in particular, French intellectuals. Roger Friedland and Deirdre Boden, in their introduction to NowHere: Space, Time and Modernity, contend "that thinking with space and time results both in deeper theoretical insight in and broader practical application of the contemporary critique of modernity" (1; original italics); such practical application applies to understanding how the individual and the environment are decidedly inseparable since our very existence is defined in time and space. Space, as Foucault argues, may not be extracted from time, instead there exists a "fatal intersection" (46) of the two, by which spaces are traceable through an indelible historicized period. Contemporary work on theorizing urbanity, by anthropological and sociological critics such as Marc Augé, Bruce Janz, Adian Southall, and Verena Andermatt Conley, for instance, endeavor to delineate the metropolitan environment, opening it up for analytical dissection. Places, postulates Augé, share the combined attributes "of identity, of relations and of history," and are "both spatial and social" (43). From the moment of birth we are associated with a place, thereby generating a traceable and historical narrative. For each of us, our human body participates in the intersection of space and time through our individual associations with place: "the extent of place is less broad than we presume when place is taken to be merely a portion of space. Place has an intensity and intimacy familiar to the lived bodies that inhabit it" (Casey 242). The crucial aspect of the relationship between the "lived bodies" and spaces is the crisis of overpopulation of regions. Threatening the modern city are extreme levels of congestion; likewise, "[c]onflicts for space often [translate] into conflicts for identity" (Ward and Zunz 11), in terms of social association and individual uniqueness. Furthermore, a megalopolis, such as New York, is "more likely to become the locus of identity conflicts than to transcend such conflicts" (Davis and Duren 1). An understanding of individuality and identity within the modern city translates into a better understanding of how environment imposes itself on both our bodies and our interactions with place, space and time.

6 In The Production of Space, Lefebvre contends that conceptualized domains between mental and physical space are often obscurely defined realms. Instead, overlapping occurs across a variety of representational spaces; he cites specific examples of imbricated spaces for "leisure, work, play, transportation, public facilities" (Production 8), all incorporated within architecture, urbanism or social planning. These multifold realms converge, creating "an indefinite multitude of spaces, each one piled upon, or perhaps contained within, the next." Conscious of its apparent obviousness, Lefebvre posits that "(Social) space is a (social) product," arguing that "[s]ocial space... ceases to be indistinguishable from mental space" (Production 26-27; original italics); Lefebvre makes the interconnection between space-or spaces-and the self, and such interaction between the variety of spheres creates a joint relationship between the self and the man-made, produced environment. Our experiences, therefore, are both mental and physical, and the physical element is composed of multiple spaces, interacting through our daily life. Personalizing such experiences, ${ }^{\text {iii }}$ prominent Finnish architect Juhani Pallasmaa, in The Eyes of the Skin: Architecture and the Senses (2005), accentuates the inability of the city inhabitant to repel an interchange between self and space: "I experience myself in the city, and the city exists though my embodied experience. The city and my body supplement and define each other. I dwell in the city and the city dwells in me" (43). 


\section{Miss Lonelyhearts's City}

7 Thus far, I have established the inextricable relation with which we, as individuals, become enveloped within the environment. The fusion of space and the individual serves as a springboard for our analysis of place and space within West's novella. Locales within the narrative illustrate how personal and public spaces detrimentally precipitate the psychological downward spiral of the protagonist. The narrative generates a "kind of fragmentary, machine-like experience associated with the loss of aura" (Barnard 205), as it represents late 1920s New York City, replete with urban advancements (high-rises) and urban decay (a desiccated park), and founders in rejuvenating the distressed protagonist. Locational significance present in our daily life did not escape West's artistic eye; place and space are clearly established in Miss Lonelyhearts, as all but one chapter begins with a place-referent. ${ }^{\text {iv }}$ Miss Lonelyhearts's identity is at risk of fracturing owing to the forceful impact of the urban environment. The narrative evinces the ingurgitating locales, "[revealing] an unsuspected depth to urban alienation" (Wisker 61), in which Miss Lonelyhearts can hardly surmise that he is mentally slipping into a deranged and radical identity. In "Some Notes on Miss L.," West reveals the he intentionally composed the narrative so that "[e]ach chapter instead of going forward in time, also goes backward, forward, up and down in space like a picture" (401). Accomplishing this agenda requires a keen ability for constructing a strategically depicted spacial environment, resulting in an aerial view of the story's scenes.

8 To briefly outline the narrative, Miss Lonelyhearts is employed as a newspaper columnist in charge of writing advice for the troubled readers of a New York City newspaper; however, his mental state is already faltering, and he seldom meets the submission deadlines for the column. Ironically, he himself is in need of the most counseling as he suffers throughout the course of the story from an encompassing Christ Complex, an impression that Christ has ordained him to succor the troubles of his readers. Crossing the boundary between author and readership, Miss Lonelyhearts has a rendezvous in a city park with a loyal reader, Mrs. Doyle; a brief sexual encounter occurs in his apartment, leaving Miss Lonelyhearts even more distraught due to failed interpersonal communication. Shortly thereafter, in a basement speakeasy, Miss Lonelyhearts is introduced to Mr. Doyle, and the two men struggle to communicate in the murky environment. Putting writing aside, Miss Lonelyhearts attempts to mend the Doyle's broken marriage. Yet, the columnist only exacerbates the situation, as events turn violent. The novel culminates when a vengeful Mr. Doyle visits the columnist's apartment. At this point, suffering from a complete mental breakdown, Miss Lonelyhearts believes that Doyle's presence signifies a sign from God; a scuffle ensues on the stairwell-a crucial locational space for the climax-as the columnist runs to embrace Mr. Doyle, and Miss Lonelyhearts is presumably shot and killed by his loyal reader.

9 The prosodic sparseness of Miss Lonelyhearts is epitomized in West's control of location in the novel. Of paramount importance is the city park, functioning as the "central node" (Rozelle 102) of the novel, where the distressed protagonist, at one point, nearly comprehends his girlfriend's admonishment that "all his troubles were city troubles" (West 95). Structurally separated from the high-rises by which it is surrounded, the park illuminates Miss Lonelyhearts's vulnerability to the influences of 
environment, as his "melodramatic and often fraudulent broodings in the park are laughable, [yet] his visions are those of his place" (Rozelle 104). An element of trickery underlies the events as they develop in relation to place. Part of the comical nature of the rapid narrative, Miss Lonelyhearts's attempts to reinvigorate himself emphasize the misdirected purposes of modern urban public and private realms. The adjectives, verbs and nouns depict a warped, antipastoral environment filled with degenerate flowers, blotched lawns, soiled fields, tortured plants, and spike-like herbage.

10 As a form of urbanized nature, the park represses its visitors, being surrounded by mechanical structures and subjugated through the force of a produced rather than a natural, pastoral space. Miss Lonelyhearts's chosen route to a local speakeasy causes him to pass through the park; he entered "at the North Gate and swallowed mouthfuls of the heavy shade that curtained its arch" (West 63), reminiscent of the urban city depicted in The Waste Land (1922), with an "Unreal City / Under the brown fog of a winter noon" (Eliot 136). vi A byproduct of the encroaching mechanical environment, his senses are blunted with a miasma of "artificially heated" (63) air and a "gray sky [that] looked as if it had been rubbed with a soiled eraser" (64). He walks through a shadow of a lamppost and envisions its spear-like resemblance piercing his body. The shadow generates both a physical image of violence as well as a symbolic threat to the vulnerable nature of Miss Lonelyhearts's personal self. Being symbolically pierced by a spear-shaped shadow, outside of its Christological connotation, intimates the depth of Miss Lonelyhearts conscious-or sub-conscious-awareness concerning the oppressiveness of his urban surroundings. Tired, and resting on a bench, he becomes aware that he is "heavy with shadow." The arch under which he passes severs the urban street from the produced (un)natural space. The interurban backdrop that incorporates the park is what Lewis Mumford, in The Culture of Cities (1938), categorizes as an outer physical realm; to absorb such spaces, the observer must successfully interface the outer with the inner: "for the outer environment to function effectively, man must face it, seize it, assimilate it: and when that is done, it is no longer an outer environment" (303-304); yet, crucial for understanding our protagonist, what develops if the environment itself is devalued to a point of ineffectiveness?

11 Elaborating on Jean Baudrillard's assessment of the scarcity of space, Verena Conley explains that "[w]hen social relations were based on transcendent or fixed values, there existed a clear demarcation between inside and outside, private and public.... With no moral value, functional places are simply integrated in a structural system of value" (51). The linking of morality and architecture has found voice in the work of Le Corbusier and Giedion, specifically. In the controversial Morality and Architecture (1977), David Watkin posits that Le Corbusier's Vers une Architecture (1923) "[preached] of a chosen type of architecture as an inescapable natural and moral commitment" (44). The extent to which moral design can be implemented into architectural design has been hotly contested over the past century. In West's fictional world of the late 1920s New York City, Miss Lonelyhearts struggles with providing a moral compass for his disturbed following of readers, as he slowly begins to surmise that the very environment of the city is inextricably entwined within the faltering value system of the culture. Even so, Miss Lonelyhearts designs to resuscitate the irreparable park, to revive it for his purpose of providing a sanctuary from the menacing megalopolis. 
12 The park, a polarized source of nature, signals the developing mental fatigue of Miss Lonelyhearts, precipitating his eventual complete psychological breakdown. Within the small park, Miss Lonelyhearts delves into his most "spacial" thinking by examining the encroaching urban landscape. His passing thoughts, provided by the omniscient narrator, integrate a conscious awareness of the creation and destruction of space, generated through architectural design. Pondering his location, Miss Lonelyhearts converts to what Lefevbre would label an urbanist; defined in The Urban Revolution, Lefevbre styles an urbanist as one who "imagines himself caring for and healing a sick society.... He perceives spatial diseases, which are initially conceived abstractly as an available void.... Eventually, space itself becomes a subject. It suffers, grows ill, must be taken care of so it can be returned to (moral) health" (157). Stopping for a moment in the park, Miss Lonelyhearts concentrates attention on the park's diseased, barren condition:

As far as he could discover, there were no signs of spring. The decay that covered the surface of the mottled ground was not the kind in which life generates. Last year, he remembered, May had failed to quicken these soiled fields. It had taken all the brutality of July to torture a few green spikes through the exhausted dirt.

What the little park needed, even more than he did, was a drink. Neither alcohol nor rain would do. To-morrow, in his column, he would ask... his correspondents to come here and water the soil with their tears. Flowers would then spring up [.] (63)

Believing the park to be repairable, Miss Lonelyhearts idealizes his therapeutic ability. What occurs is the delusional desire to have the power to aid; or, as Lefebvre further describes, "[t]he urban illusion culminates in delirium. Space, and the contemplation of space, leads the thinker down a hazardous avenue. He becomes schizophrenic and imagines a mental illness-the schizophrenia of society-onto which he projects his own illness, space sickness, mental vertigo" (Urban 157). The sickness in Miss Lonelyhearts is intensified by the sickness he sees in the park, onto which he imagines placing a healing hand.

14 Stepping away briefly from the narrative, the richness of West's prose and his literary depiction of mental space and physical world are further conjoined through his specialty of manipulating and repeating words. The word "stone" appears fourteen times throughout the narrative. Its initial function is metaphorical, employed by Shrike, the newspaper director, who apathetically counsels Miss Lonelyhearts on how to influence his readership: "Explain that man cannot live by bread alone and give them stones," further recommending that they start each day with the prayer, "Give us this day our daily stone." Sitting in the park, Miss Lonelyhearts comprehends that such advice is worthless, as "[h]e had given his readers many stones; so many, in fact, that he had only one left-the stone that had formed in his gut" (63). In Miss Lonelyhearts's opinion, his counseling, as "stones", miscarries on a catastrophic level, neither being digested by his readers nor advancing their quest for solutions. Later uses of the word represent it in physical form; in these cases, "stone" remains connected with what Miss Lonelyhearts views as mankind's destructive nature and incapacity for creative construction. Returning to the park later in the narrative, Miss Lonelyhearts inspects his surroundings from a park bench. From his position he

turned his trained eye on the skyscrapers that menaced the little park from all sides. In their tons of forced rock and tortured steel, he discovered what he thought was a clue.

Americans have dissipated their radical energy in an orgy of stone breaking. In their few years they have broken more stones than did centuries of Egyptians. And 
they have done their work hysterically, desperately, almost as if they knew that the stones would some day break them. (89) despite the fact that the novella is rife with emotional turmoil, it also illuminates the sociological forces brought on by the physical surroundings, as "[s]tructures are both the medium and the outcome of social practices" (Pearson and Richards 2). By considering the manipulation of stone, West is in many respects giving voice to a protest against what Le Corbusier defines as a revolution in architecture. Le Corbusier hypothesizes:

The history of Architecture unfolds itself slowly across the centuries as a modification of structure and ornament, but in the last fifty years steel and concrete have brought new conquests, which are the index of a greater capacity for construction, and of an architecture in which the old codes have been overturned. If we challenge the past, we shall learn that 'styles' no longer exist for us, that a style belonging to our own period has come about; and there has been a Revolution. (Towards 7)

The adjectival differences between Le Corbusier and West's depiction of "forced rock" and "tortured steel" emphasize their critical differences of a psychological dismemberment evolving from the architectural advances of the previous half-century. In the narrative, Miss Lonelyhearts's inefficacious efforts to uncover any logic within his physical, stone-breaking environment merely demonstrate how little meaning is derived from the "greater capacity for construction" of the Modern age. Instead, the revolution in style conceivably produces an erasure of human interconnections.

17 As the fast-paced plot of Miss Lonelyhearts develops, the symptomatic consequences of modernity surfacing in West's protagonist become both more complicated and more dangerous as Miss Lonelyhearts moves from public to private realms of the urban landscape in an attempt to restore his inner self. In Space, Time and Architecture (1941), Sigfried Giedion explains a theoretical conjunction of early modernist thought

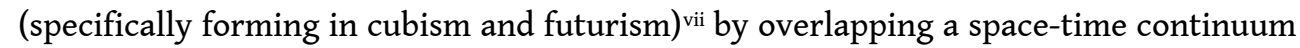
of "contemporaneous feelings." Such "unconscious parallelisms" arose from efforts to revive the fragmented inner life of modern man, as, Giedion claims, the language of design between artists and scientists no longer permitted meaningful communication. The individual man, then, is tossed through the sea of a disjointed civilization: "This orientation of the vital energies... is reflected in the make-up of the man of today. Scarcely anyone can escape the unbalanced development which it encourages. The split personality, the unevenly adjusted man, is symptomatic of our period" (14). Le Corbusier and Giedion propose advancements in architectural design to readjust, so to speak, contemporary man to his environment. Nevertheless, West's depiction of his protagonist and surrounding environment does not reflect an architectural development that encourages the realignment of an "unevenly adjusted man."

\section{Spirits from the Underground}

18Although secluded beneath the city street, the local speakeasy serves as a predominantly public gathering place in Miss Lonelyhearts and is the narrative's best example of the overlapping of physical and social environment. The recurring locales in the novella illustrate the "time, space and repetition in social life" (Giddens 205), and, accordingly, several crucial events for the storyline transpire in the murky bar 
atmosphere. The speakeasy's inner space provides an isolated stage in which West can micro-analyze the urban environment. Patronized principally by male customers who spend their time disparaging women and lamenting their own social status, the speakeasy is a space dominated by macho prowess, ironically located not below a place of commerce, but "in the cellar of a brownstone house that differed from its more respectable neighbors by having an armored door" (West 64). Placing the speakeasy in the basement of a house displaces this hyper-masculine domain, generating a disparity between the physical environment of the house and the social backdrop. In 1929, German architect Bruno Taut intimated that architectural design could advance intellectual capacity: "the people who use the building for any purpose, will, through the structure of the house, be brought to a better behavior in their mutual dealings and relationship with each other. Thus architecture becomes the creator of new social observances" (qtd. in Watkin 47). Taut suggests that architecture itself may generate, from a tabula rasa, meaningful social value for the occupants of various architectural spaces. In West's text, the characteristics of the patrons behind the armored speakeasy door are degenerative, destroying, not creating, any new social observances. The house, in a sense, has been misappropriated for ulterior motives.

19 Considering the idealized function of a house or home, Gaston Bachelard suggests that its essential elements comprise "a body of images that give mankind proofs or allusions of stability" (17). The necessity of stability surfaces when examining the brownstone house with the armored door-as well as the seclusion from the streetcreate the allusion of constancy as demonstrated through the patrons of the speakeasy. West's description of the speakeasy conveys how each individual experience "is governed by and utilizes the architectural structures we perceive, as we perceive them" (Frank 4-5). In partial harmony with Taut's theories, space impacts the individual-but not necessarily in a positive manner. The social space of the barroom operates more as a failed murky sanctuary where the male patrons endeavor to separate overlapping social spaces from their idealized masculine domain. Here, they attempt to arrest the reality that, in their opinion, the external world is becoming increasingly less maledominated and homogenous-daring to suggest the gang rape of transgressing females. More specifically, if we focus on the cellar as a specific place, Bachelard theorizes that it "is first and foremost the dark entity of the house, the one that partakes of subterranean forces. When we dream there, we are in harmony with the irrationality of the depths" (18; original italics). Bachelard alludes to the Freudian postulation that the cellar is where our painful experiences are repressed and stored by the unconscious; in the cellar, the unspeakable may be enacted. As the narrator explains, the speakeasy allows Miss Lonelyhearts a place to "settl[e] into the warm mud of alcoholic gloom" (West 64). It creates a supposed space of stability that is architecturally secluded from the street by its very construction, secluded from the "[c]rowds of people [moving] through the street with a dream-like violence" (West 104). The cellar atmosphere assumes negative characteristics through retaining the dysfunctionality inherent in a masculine-dominated society. These traits are emphasized through the presence of the refuge-seeking drinkers, who, in their alcohol-induced lucidity, realize that "the trouble with all of us... is that we have no outer life, only an inner one, and that by necessity" (75). The underground space delivers to the men the needed allusion of stability from which they can grasp onto their meager inner life. 
20 As the violence in the narrative unfolds, the speakeasy setting produces aggressive images and actions. West believed that violence was at the very heart of American culture, as his oft-cited short theses "Some Notes on Violence" and, in particular, "Some Notes on Miss. L.," demonstrate. "Violent images are used to illustrate commonplace events" (401), West informs, and such depictions contort the speakeasy milieu into a military battleground with smoke, explosions, and artillery-perhaps representing the battlefield of the repressed subconscious: "Through the light-blue tobacco smoke, the mahogany bar shone like wet gold. The glasses and bottles, their high lights exploding, rang like a battery of little bells when the bartender touched them together" (75). Drinking and watching the routines of the barman, Miss Lonelyhearts drifts into a reverie of his sister dancing in their childhood home; he begins imagining all children dancing in geometrical form, as "[s]quare replacing oblong and being replaced by circle" (76). The geometrical shapes replace the dancers, eradicating their individuality by confining them to transmuting rigid forms. Inextricably linked with identity, memory can be located in its own space, as a "focus on memory," argues Andreas Huyssen, in Present Pasts, files into "categories of space... and cultural studies" (11). Recalling Bachelard, the dream within the "cellar" of the mind, brings the dreamer into "harmony with the irrationality of the depths." The distant memory momentarily removes Miss Lonelyhearts from his surroundings, providing him a glimpse back to an era of childhood innocence; however, snapping back to his reality and moving from his spot at the bar, he collides with a man holding a beer. Before he can apologize, the man punches Miss Lonelyhearts, sending him the floor and leaving him to nurse a bruised head. Memory entails inner space, and Miss Lonelyhearts's regression from outer towards inner space suggests that the more personal the space, the more physically violent and unfeeling the outer world is in comparison.

\section{Unhomely Space}

21 Unlike the city park and the speakeasy, the home of the protagonist would ideally function as a personal environment; yet, in this defined space, he achieves no reprieve from the outside world. The apartment space appears early in the novella and eventually serves as the backdrop for the climatic action. Far from a sparing safehaven, it resembles an oppressive chancel-like residence: "He lived by himself in a room that was as full of shadows as an old steel engraving. It held a bed, a table and two chairs" (67), viii barren of decoration except for a cross nailed to the wall. ix It is a simulacra of a pious yet defiled church, with the ivory Christ detached from the cross and "hung opposite the foot of the bed" (67). Both Heidegger and Bachelard consider the house, or dwelling, existing in a relatively secluded place, so as to be fortified against other urban spaces. For Heidegger, in "Building Dwelling Thinking," various places may be construed for a person to repose (but not necessarily call 'home'); these he defines as dwellings, where to dwell is "to be set at peace, [it] means to remain at peace within the free, the preserve, the free sphere that safeguards each thing in its nature. The fundamental character of dwelling is this sparing and preserving" (148; original italics). Additionally, Bachelard explains that "house", is an object which has "the chief benefit" of "shelter[ing] daydreaming, the house protects the dreamer, the house allows one to dream in peace" (6). In West's depiction, instead of correlating the apartment with an image of peaceful privacy, we find the modern image of "dwelling" 
being distorted. Rented apartment spaces are commodities; as Neil Leach explains, such commodification of place generates a "fundamental shift in the ways in which we relate to the world. Not only must we question the primacy of the concept such as 'dwelling' as a source of identification, but we must also ask whether a concept which is so placespecific can any longer retain much authority" (155). Miss Lonelyhearts's apartment serves as a place in which the columnist sleeps off his alcoholic binges; yet, the room fails to ease his own doubts of identity. At one point, following a tiff with his girlfriend, Betty, Miss Lonelyhearts deliberates on where to go next, revealing his consciousness concerning his ineffective living environment, as he was "afraid to go home" (74). Home for Miss Lonelyhearts fails to achieve a stabilizing peace of the mind.

22 Early descriptions of Miss Lonelyhearts reveal his struggles to create a structured environment, manipulating the artificially controllable space of his apartment to serve as a miniature counterpart for the larger, outer world. In his room, "Miss Lonelyhearts found himself developing an almost insane sensitiveness to order. Everything had to form a pattern: the shoes under the bed, the ties in the holder, the pencils on the table" (70). Miss Lonelyhearts's actions are his attempts to organize both his inner and outer life. The mental impact of the urban environment, Simmel argued in 1903, requires an ability to manage the subjectivity of the modern environment: "the technique of metropolitan life in general is not conceivable without all of its activities and reciprocal relationships being organized and coordinated in the most punctual way into a firmly fixed framework of time" (328). Comprehending his outer environment has noticeably failed, developing in Miss Lonelyhearts a neurotic fetish for controlling his inner, personal spaces. The daily struggle for control ascends from the abstraction of the physical, external world-plausibly, the removal of distinct symbols causes the individual to attempt to assemble their own reality-arising from what Baudrillard, in The System of Objects, deems is "the notion of a world no longer given but instead produced-mastered, manipulated, inventoried, controlled: a world, in short, that has to be constructed" (28; original italics). Yet, unable to organize the external realm, Miss Lonelyhearts recedes into his inner world in an attempt to organize and control the placement of his belongings; additionally, the barrenness of the columnist's apartment suggests a larger, social disconnection. The narrator informs us that Miss Lonelyhearts has maintained an austere protestant resemblance in his décor and possessions. Examining the columnist's apartment, we should consider that "[n]o dwelling is static and fixed in time," unless the occupant is resistant to change; additionally, we would expect that "each dwelling mutates as fortune and human circumstances change" (Knapp 8). The location of Miss Lonelyhearts's apartment is unclear, but he apparently lives in a building with remote access to the street. His simplistic compartment encapsulates him and contrasts the exuberance of the New York City environment. Between historical past and the static condition of the present, a correlation surfaces involving the identity of Miss Lonelyhearts within the austere and nonregenerative design of his apartment.

23 The private residence is also a constructed realm and, as such, is an environment historically connected with the identity of the inhabitant. Therefore, let us consider for a moment that the unease experienced by Miss Lonelyhearts may indeed be attributable to his past. Writing in 1914, Edith Wharton and Ogden Codman, Jr. published what they believed to be the first "study of house-decoration as a branch of architecture" (xx; original italics) in nearly fifty years. The authors conjecture that, 
"every one is unconsciously tyrannized over by the wants of others,-the wants of dead and gone predecessors.... The unsatisfactory relations of some people with their rooms are often to be explained in this way" (Wharton and Codman 19). Wharton and Codman provoke a correlation, though merely hypothetical, which is ascribable to the protagonist and his past. The "son of a Baptist minister," with the appearance of "the New England puritan" (West 61), Miss Lonelyhearts has, perhaps subconsciously, arrayed his apartment symbolizing a continuance of his heritage. But, the narrative demonstrates that it is not merely personal possessions that unhinge the protagonist; it is also the shadows in the room, the view from his window, and the objects within this physical space, all of which are taunting him in his own unrealized identity. Architecture, John Ruskin believed, is directly tied to memory: "We may live without her [memory], and worship without her, but we cannot remember without her" (169). The past may well be part of Miss Lonelyhearts's identity, but the architectonic environment surrounding his daily life aggressively infringes on his mental space causing a disjuncture between his past and his present, as demonstrated by the violent awakening from his childhood recollection of his sister while in the speakeasy.

24 As Miss Lonelyhearts struggles to control his living environment, he is incapable of assimilating its space as it too closely overlaps with the imposing architecture of the city. A constant observer of environment, he visually attempts to manipulate the external surroundings of his apartment: "When he looked out of a window, he composed the skyline by balancing one building against another. If a bird flew across this arrangement, he closed his eyes angrily until it was gone" (70). To generate a skyline is his intent, not to redefine specific buildings; however, he does use the buildings to create "regulating lines," deemed necessary by Le Corbusier for "harmony" in an architectural system (Towards 72). Nevertheless, the columnist is exposed to the spacial disarray within his architectural horizon, a "splintered utopia" (Augé xvii), predominating the urban world, in his fidgety struggle to restructure his environment. Near the window, he stands at the "transparent cut between inside and out" (Vidler 13), being present in the inner space of his apartment while observing the outer space of the larger metropolis. He becomes desperate to keep various spaces linear and defined-yet, when distorted through the presence of a bird, he is incapable of maintaining control. Miss Lonelyhearts's "agony is the acute perception of the antiorder of [his] times, the incompatibility of his city experiences to any ordering and coherence" (Widmer 101-102). The bird's trajectory disorders the protagonist's field of vision, demonstrating an overreliance on the physiognomy of his surroundings: "[w]hen a person's visual relation to his environment is so crucial to his sense of self, and that environment's visual aspect is increasingly dominated by monumental, abstract, empty space, the conditions are set for an eruption of anxiety over the visiondominated self's loss of control" (Milun 117). Beginning to realize that his reality lacks satisfactory patterns, he seeks to organize the personal, physical objects of his modest apartment; then, moving to the window, he set his sights on restructuring the urban sprawl to remove the abstract and empty space below the skyline-in this undertaking, he ultimately fails.

25Regarding Miss Lonelyhearts's tactics for coping with his environment, the narrator informs us that, "[f]or a little while, he seemed to hold his own but one day he found himself with his back to the wall. On that day all the inanimate things over which he had tried to obtain control took the field against him" (70). Again, West's choice of wording suggests a battle ground between the individual and his environment, as the 
columnist tries to "hold his own," but figuratively finds his "back to the wall," with inanimate objects in his apartment "[taking] the field against him." Believing that the apartment has spiraled out of his control, Miss Lonelyhearts flees to the street, only to discover "there chaos was multiple;" to deflect the cacophony of the street, Miss Lonelyhearts "stood quietly against a wall, trying not to see or hear" (70). In this continued instance of fear, the inner and outer environments converge on the protagonist and trigger an agoraphobic anxiety attack. In these two brief scenes, the metaphorical and corporeal walls of his environment merge-exemplifying Lefebvre's argument that mental and physical spaces overlap. Panic disorders materialize in Miss Lonelyhearts in his apartment, the street, and in the city park as he sits staring at a Mexican War obelisk. Walter Benjamin thought that such occurrences are symptomatic of urban space. In "One-Way Street," Benjamin explains that "[t]he insecurity of even the busy areas puts the city dweller in the opaque and truly dreadful situation in which he must assimilate... the abortions of urban architectonics" (454). After multiple efforts by Miss Lonelyhearts to vainly assimilate to his urban situation, the environmentpromoted downward spiral into his deranged state of Christ-ordained-columnist culminates in violence on his apartment stairwell.

26 As the novella closes, Miss Lonelyhearts has succumbed to another mental breakdown, as lack of cohesion in his life, amidst the abstract city spaces, has predestined his collapse. From his bed, he realizes that, except for the image of Christ hanging on the wall, "[e]verything else in the room was dead-chairs, table, pencils, clothes, books" (West 125). At this point, he has exceeded the mindset of the urbanist, and is no longer intent on healing. The apartment environment has proven to be devoid of the qualities of peace, preserving, and protection-crucial requisites that Heidegger and Bachelard outline for dwelling space. Twice during the novella the word "dead" is linked to the apartment, thereby equating death and physical space. In the initial apartment scene, Miss Lonelyhearts contemplates, "how dead the world is...a world of doorknobs" (67-68). Doorknobs, of course, are structural devices engaged in opening and closing doors, and by extension, the opening and closing of spacesPallasmaa describes them as "the handshake of the building" (62)-in this case, however, they are linked with a dead material world. Miss Lonelyhearts's contemplations reveal his cognition of the unfulfilled and lifeless spaces, or even immaterialized spaces. The connection between the death that he senses within his apartment (personal space) and the almost humorous comparison to a dead world of doorknobs (architectural) inescapably brings architecture and inner spaces into an amalgamated joint relationship with each other.

\section{Stairwell to Nowhere}

27 As with each previous event in the narrative, the location of the climatic action is distinctly established. In this final section, I illuminate the reason why West's novella fittingly closes with the protagonist on a stairwell. ${ }^{\mathrm{x}}$ In order to do so, I borrow a term defined by Marc Augé: the Non-Place. ${ }^{\mathrm{xi}}$ For Augé, a non-place represents architecturally delineated space that does not signify or carry sufficient qualities defining it as a place, and he associates such non-places within the time-space constructs of supermodernity. Augé terms a place as "at once spatial (relational), temporal (historical) and linked to identity (individual)" (Conley 71); places that do not achieve these qualities are labeled 
as non-places. Therefore, by this definition, we could label the park, the speakeasy, and the apartment as distinct places. "Non-places are there to be passed through" (Augé 83) in an isolated manner, and such passing is exactly the function of the stairwell to Miss Lonelyhearts's apartment. Being summoned from his sickbed by the doorbell, Miss Lonelyhearts is greeted with the sight of Mr. Doyle ascending the stairs. We will remember that Mr. Doyle is a "cripple" and a cuckolded husband who is now bent on revenging himself and his wife. In his delirium, Miss Lonelyhearts presumes that Doyle's presence is a sign from God, and the columnist rushes down the steps to embrace his loyal reader. Doyle perceives the columnist's descent as a confrontation, and he shouts out an unheeded warning. As the columnist and Doyle collide on the steps, the gun which Doyle has been concealing "exploded and Miss Lonelyhearts fell, dragging the cripple with him. They both rolled part of the way down the stairs" (126). Thus ends the novel; we receive no clarification as to who was shot or if anyone was killed; neither is there any tone of sadness from the narrator. The final act, like many scenes in the novel, uses the terminology of the battlefield, with Miss Lonelyhearts charging towards Mr. Doyle's exploding gun. Numerous critics have commented on the sparseness of the conclusion, and some have even noted that both men fail to roll completely down the stairwell and into the street. In the non-place of the stairwell, identity is defunct as the individual belongs in place and space, which are "major categories for people wherever identity and reciprocal relations are countenanced.... [P]lace is where people live and dwell" (Conley 68). Therefore, it is fitting that West concludes his novella in such a fashion: Miss Lonelyhearts's removal from his apartment, which has continually retarded the development of his identity and individuality, almost requires his moving into a non-place, for it presages the final effacement of identity brought on by a structurally defined space. Once the individual has been destroyed, the incidents surrounding the body are ultimately inconsequential.

28 West's depictions of the New York City environs illuminate an unwelcoming landscape of space, place, and time all of which become menacing factors in the life of the protagonist. The inconclusive final events, with Miss Lonelyhearts presumably being shot and left in the "non-place" of the stairwell, reveals how West's modern urban spaces decisively destroy identity and annihilate the individual. The city park, the underground speakeasy, and the apartment filled with "dead" objects prevent Miss Lonelyhearts from realizing the figure of the modern metropolitan man; rather, the city bombards him, exacerbating his agoraphobic nature and drives him into seclusion and delirium. By approaching Miss Lonelyhearts with this sociological perspective toward the narrative, and a sharp examination of the city structures, the outcome clearly demands that the failed formation of Miss Lonelyhearts's individuality and identity require his body to be left in a place that is devoid of spatial consequence.

\section{BIBLIOGRAPHY}

Augé, Marc. Non-places: An Introduction to Supermodernity. London: Verso, 2008. Print. 
Bachelard, Gaston. The Poetics of Space. Trans. Maria Jolas. Boston: Beacon, 1994. Print.

Barnard, Rita. The Great Depression and the Culture of Abundance: Kenneth Fearing, Nathanael West, and Mass Culture in the 1930s. Cambridge: Cambridge UP, 1995. Print.

Baudrillard, Jean. The System of Objects. Trans. James Benedict. London: Verso, 2005. Print.

Benjamin, Walter. “One-Way Street.” Selected Writings: Volume 1, 1913-1926. Ed. Marcus Bullock and Michael W. Jennings. Vol. 1. 5 vols. Cambridge: Harvard UP, 2004. Print.

Bohn, Willard. Marvelous Encounters: Surrealist Responses to Film, Art, Poetry, and Architecture. Cranbury: Associated University Presses, 2005. Print.

Casey, Edward S. The Fate of Place: A Philosophical History. Berkeley: U of California P, 1997. Print.

Conley, Verena Andermatt. Spatial Ecologies: Urban Sites, State and World-Space in French Critical Theory. Liverpool: Liverpool UP, 2012. Print.

Crosby, Robert. "Nathaniel West Stranded Between 'Art' and 'Life."' The Harvard Crimson 28 (July 1970). Web. 5 Nov. 2013.

Davis, Diane E., and Nora Libertun de Duren. "Introduction: Identity Conflicts in the Urban Realm." Cities and Sovereignty: Identity Politics in Urban Spaces. Ed. Diane E. Davis and Nora Libertun de Duren. Indianapolis: Indiana UP, 2011. 1-14. Print.

Eliot, Thomas Stearns. The Waste Land: A Facsimile and Transcript of the Original Drafts, Including the Annotations of Ezra Pound. New York: Harcourt, 1974. Print.

Foucault, Michel. "Of Other Spaces, Heterotopias." Architecture, Mouvement, Continuité 5 (1984): 4649. Print.

Frank, Ellen Eve. Literary Architecture: Essays Toward a Tradition: Walter Pater, Gerard Manley Hopkins, Marcel Proust, Henry James. Berkeley: U of California P, 1979. Print.

Friedland, Roger, and Deirdre Boden. "NowHere: An Introduction to Space, Time and Modernity." NowHere: Space, Time and Modernity. Ed. Roger Friedland and Deirdre Boden. Berkeley: U of California P, 1994. 1-60. Print.

Fuchs, Miriam. "Nathanael West's Miss Lonelyhearts: The Waste Land Rescripted." Studies in Short Fiction 29.1 (1992): 43-55. Print.

Giddens, Anthony. Central Problems in Social Theory: Action, Structure, and Contradiction in Social Analysis. Berkeley: U of California P, 1979. Print.

Giedion, Sigfried. Space, Time and Architecture: The Growth of a New Tradition. Cambridge: Harvard UP, 1967. Print.

Hattenhauer, Darryl. “West’s Miss Lonelyhearts.” Explicator 49.2 (1991): 120-121. Print.

Heidegger, Martin. Poetry, Language, Thought. Trans. Albert Hofstadter. New York: Harper \& Row, 1971. Print.

Huyssen, Andreas. Present Pasts: Urban Palimpsests and the Politics of Memory. Stanford: Stanford UP, 2003. Print.

Jay, Martin. Cultural Semantics: Keywords of Our Time. Amherst: U of Massachusetts P, 1998. Print.

Keyes, John. "Nathanael West's 'New Art Form': Metamorphoses of Detective Fiction in Miss Lonelyhearts." English Studies in Canada 8.1 (1982): 76-86. Print.

Klug, M. A. "Nathanael West: Prophet of Failure." College Literature 14.1 (1987): 17-31. Print. 
Knapp, Ronald G. China's Living Houses: Folk Beliefs, Symbols, and Household Ornamentation. Honolulu: U of Hawaii P, 1999. Print.

Le Corbusier. The Radiant City: Elements of a Doctrine of Urbanism To Be Used as The Basis of Our Machine-Age Civilization. London: Orion P, 1964. Print.

---. Towards a New Architecture. New York: Payson \& Clarke, 1927. Print.

Leach, Neil. "The Dark Side of The Domus: The Redomestication of Central and Eastern Europe." Architecture and Revolution: Contemporary Perspectives on Central and Eastern Europe. Ed. Neil Leach. New York: Routledge, 2004. 150-62. Print.

Lefebvre, Henri. The Production of Space. Trans. Donald Nicholson-Smith. Malden: Blackwell, 1992. Print.

---. The Urban Revolution. Trans. Robert Bononno. Minneapolis: U of Minnesota P, 2003. Print.

Martin, Jay. Nathanael West: The Art of His Life. New York: Farrar, 1970. Print.

Milun, Kathryn. Pathologies of Modern Space: Empty Space, Urban Anxiety, And the Recovery of the Public Self. New York: Routledge, 2007. Print.

Mumford, Lewis. The Culture of Cities. New York: Harcourt, 1938. Print.

Nieland, Justus. “West's Deadpan: Affect, Slapstick, and Publicity in Miss Lonelyhearts.” Novel 38.1 (2004): 57-83. Print.

Pallasmaa, Juhani. The Eyes of the Skin: Architecture and the Senses. West Sussex: Wiley, 1996. Print. Pearson, Michael Parker, and Colin Richards. "Ordering the World: Perceptions of Architecture, Space and Time." Architecture and Order: Approaches to Social Space. Ed. Michael Parker Pearson and Colin Richards. New York: Routledge, 2004. 1-33. Print.

Rozelle, Lee. 'Ecocritical City: Modernist Reactions to Urban Environments in 'Miss Lonelyhearts' and 'Paterson."' Twentieth Century Literature 48 (2002): 100-115. Print.

Ruskin, John. The Seven Lamps of Architecture. New York: Dover, 1989. Print.

Simmel, Georg. "The Metropolis and Mental Life." On Individuality and Social Norms: Selected Writings. Ed. Donald N. Levine. Chicago: U of Chicago P, 1971. 324-39. Print.

Spector, Scott. "Forum: Ideas and the City Introduction." Journal of the History of Ideas 74.2 (2013): 259-266. Print.

Strychacz, Thomas. Modernism, Mass Culture and Professionalism. Cambridge: Cambridge UP, 1993. Print.

Vidler, Anthony. Warped Space: Art, Architecture, and Anxiety in Modern Culture. Cambridge: MIT P, 2001. Print.

Ward, David, and Olivier Zunz. "Between Rationalism and Pluralism: Creating the Modern City." The Landscape of Modernity: Essays on New York City, 1900-1940. Ed. David Ward and Olivier Zunz. New York: Russell Sage, 1992. 3-18. Print.

Watkin, David. Morality and Architecture Revisited. Chicago: U of Chicago P, 2001. Print.

Watts, Jay Jr. "Greenwich Village Bows to Modernity.” The Greenwich Villager (1 Aug. 1933): 1, 4. Print.

West, Nathanael. Novels and Other Writings. New York: Library of America, 1997. Print.

Wharton, Edith, and Ogden Codman Jr. The Decoration of Houses. New York: Scribner, 1914. Print. 
Widmer, Kinglsey. "The Sweet Savage Prophecies of Nathanael West." The Thirties: Fiction, Poetry, Drama. Ed. Warren G. French. Deland: Everett Edwards, 1967. 97-106. Print.

Wilson, Edmund. Letter to Cyril M. Schneider. 19 Mar. 1952. E-mail.

Wisker, Alistair. The Writing of Nathanael West. New York: Macmillan, 1990. Print.

Zlotnick, Joan. "Nathanael West and the Pictorial Imagination." Western American Literature 9.3

(1975): 177-85. Print.

\section{NOTES}

i. Of biographical interest is the family business from which much of West's personal, but limited, funds originated, until the onset of the Depression. In the early 1920s, West was unenthusiastically involved in his father's construction business, where "he had been obliged to work on apartment houses being built by his father in the Bronx, occasionally as a bricklayer" and "as construction superintendent" (Martin 75). By 1925, West was advancing his literary interests, and after a short stint in Paris, he returned stateside, involving himself with "a seriously intellectual, masculine group, interested in the most recent developments in the world" (Martin 114); the group's European concenter would have exposed West to the burgeoning interest in Urban renewal, spearheaded by Adolf Loos, Le Corbusier and other European intellectuals.

ii. Mumford's employment of the word "style" is in sharp contrast to the rejection of the word by Le Corbusier and Giedion, who, as David Watkin explains, considered that the use of the word "style" would "open the door to a formalistic approach" (18).

iii. We must bear in mind that the noun "experience" is subjective, as German philosopher HansGeorg Gadamer observes: "'However paradoxical it may seem, the concept of experience seems to me one of the most obscure that we have"' (qtd. in Jay 47). Controversial in its paradoxical nature, it is even more difficult to analyze the experiences of a literary character as the authorial intent skews the intended perspective for narrative purposes.

iv. The place-referent at the beginning of each chapter is likely due to West's initial efforts to create the story in the form of a comic strip. Miss Lonelyhearts must, therefore, be placed in a particular space-often including a time-referent-as Thomas Strychacz alludes to in "Nathanael West's Comic-Strip Novel" (176). More pointedly, Justin Nieland views West's humor as a type of vaudevillian "New Humor," that permitted an avenue of expression demonstrating "the discontent of the immigrant urban masses with the ability of American institutions to fulfill their promises, and its economy and pace mirrored the hurried tempo of urban life, the 'hasty people' of West's imagined readership" (63).

v. Darryl Hattenhauer emphasizes that critics too easily surmise that Miss Lonelyhearts dies at the climax of the novel; it is also presumptuous, Hattenhauer argues, to assume Miss Lonelyhearts is the victim, perhaps it is Doyle who is shot, or maybe no one has been shot. Falling down the stairs together does not warrant a death certificate; all told, the ending of the novel remains "extremely ambiguous" (120-121).

vi. A few articles have examined the overlapping of Eliot's The Waste Land and Miss Lonelyhearts, as West himself made clear the connections. In "Nathanael West's Miss Lonelyhearts: The Waste Land Rescripted," Miriam Fuchs argues that "West parodies crucial elements of the poem in order to dramatize the dangers of authority outside the self" (44), and West enhances Eliot's use of the city as a signifier of a contorted, man-made landscape.

vii. West was known to have "avariciously gulped down the most fashionable aestheticsdadaism, expressionism and futurism" (Crosby) in his personal artistic exploration. 
viii. West may have lost track of the furniture ascribed to his protagonist's apartment; in a later scene, after his sexual encounter with Mrs. Doyle, Miss Lonelyhearts "dropped down into a large armchair near the window" (West 90). Mentioned solely in this instance, the armchair seems distinctly remote from the austere living environment West was painting in the initial description of the apartment.

ix. In the early drafts of Miss Lonelyhearts, published in Contact, the description of the room is altered to accommodate a mirror: "His room was furnished with a bed, a table, and two chairs. The walls were bare except for a mirror and an ivory Christ. He had removed the cross to which the figure had been delicately fastened with tiny silver nails and had spiked it to the wall. But the desired effect had not been obtained. It did not writhe; it remained calmly decorative."

x. Early drafts of Miss Lonelyhearts have the protagonist speaking in the first person; at one point he describes his residence, "I lived on a deserted stairway, among steel engravings of ornate machinery" (Contact 18). West removed this line; however, it's presence is significant, as the narrator figuratively depicts the transformation of the stairwell into a lifeless landscape as he attempts to compose responses to his readers while sitting in his apartment: "The joke of suffering and the joke of comforting killed this world. The stairway flattened into a desert [...]" (Contact 18).

xi. I am cognizant that Augé's definitions are relative to supermodernity; nevertheless, the essential definitions for the non-place strike me as being enlightening to the purpose and function of the stairwell in Miss Lonelyhearts. Stairwells, like escalators, serve as a mode of transition from one locale to another, one in which we may pass strangers without engagement or interaction.

\section{ABSTRACTS}

Nathanael West's 1933 novella, Miss Lonelyhearts, depicts a New York City that defines its inhabitants through the architectural structures enveloping them. Throughout West's narration, spaces and places within the city become social critiques, as these locations represent what Henri Lefebvre describes as abstract spaces: various spaces that are multifaceted in their functions due to their shifting-and abstract-relation with a larger environment. Fusing an analysis of space and the individual serves as a springboard for reexamining West's novella of place and space in the then modern metropolis of the 1920s. Locales within the narrative illustrate how modern public and private spaces detrimentally precipitate the psychological downward spiral of the protagonist. This article argues that by scrutinizing the physical setting in the narrative we will illuminate a new understanding of the repressed, agoraphobic identity of the protagonist, Miss Lonelyhearts, and bring a fresh phenomenological interpretation to the demise of one of West's most complicated characters.

INDEX

Keywords: architecture, identity, individuality, metropolis, Nathanael West, space 
AUTHOR

WAYNE E. ARNOLD

Kansai Gaidai University 